\title{
Corynebacterium pyruviciproducens sp. nov., a pyruvic acid producer
}

\section{Correspondence \\ Sydney M. Finegold sidfinegol@aol.com}

\author{
Jia Tong, ${ }^{1,2,3}$ Chengxu Liu, ${ }^{2}$ Paula H. Summanen, ${ }^{2}$ Huaxi $\mathrm{Xu}^{3}$ \\ and Sydney M. Finegold ${ }^{1,4,5}$
}

\footnotetext{
${ }^{1}$ Department of Medicine, University of California, Los Angeles School of Medicine, Los Angeles, CA, USA

${ }^{2}$ Research Service, Veterans Affairs Medical Center West Los Angeles, Los Angeles, CA, USA

${ }^{3}$ Schools of Food Science and Engineering and of Medical Technology, Jiangsu University, Zhenjiang, PR China

${ }^{4}$ Department of Microbiology, Immunology and Molecular Genetics, University of California, Los Angeles School of Medicine, Los Angeles, CA, USA

${ }^{5}$ Infectious Diseases Section, Veterans Affairs Medical Center West Los Angeles, Los Angeles, CA, USA
}

\begin{abstract}
A coryneform strain, 06-17730 ${ }^{\top}\left(=\right.$ WAL $\left.19168^{\top}\right)$, derived from a groin abscess sample was characterized using phenotypic and molecular taxonomic methods. Comparative analyses revealed more than $3 \%$ divergence of the $16 \mathrm{~S}$ rRNA gene sequence and about $10 \%$ divergence of the partial rpoB gene sequence from the type strain of Corynebacterium glucuronolyticum. The strain could also be differentiated from C. glucuronolyticum by a set of phenotypic properties. A DNA-DNA relatedness study between strain WAL $19168^{\top}$ and C. glucuronolyticum CCUG $35055^{\top}$ showed a relatedness value of $13.3 \%$ (13.7\% on repeat analysis). The genotypic and phenotypic data show that the strain merits classification within a novel species of Corynebacterium. We propose the name Corynebacterium pyruviciproducens sp. nov. for the novel species. The type strain is $06-17730^{\top}\left(=\right.$ WAL $19168^{\top}=$ CCUG $57046^{\top}=$ ATCC $^{\top}$ BAA $\left.-1742^{\top}\right)$.
\end{abstract}

Bacteria of the genus Corynebacterium have been recovered extensively from mammals and the environment (Feurer et al., 2004; Hommez et al., 1999). Except for Corynebacterium diphtheriae, the aetiological agent of diphtheria, most species of the genus are regarded as opportunistic pathogens (Paviour et al., 2002). Compared with those bacteria possessing proof of clinical pathogenicity, less emphasis has been put on Corynebacterium. Recently, however, a report demonstrated that Corynebacterium was the most prevalent bacterial genus associated with chronic wound infections in diabetics (possibly skin flora) (Dowd et al., 2008). In our investigation of the bacteriology of acute wound infections (Finegold et al., 2008), a novel aerobic, rod-shaped, Gram-positive corynebacterium was found. It is similar to Corynebacterium

Abbreviations: CAMP, Christie-Atkins-Munch-Petersen; CFA, cellular fatty acid; ME, metabolic end product; TBSA, tuberculostearic acid.

The GenBank/EMBL/DDBJ accession numbers for the 16S rRNA gene sequence and partial rpoB gene sequence of strain WAL $19168^{\top}$ are FJ185225 and FJ899747, respectively.

UPGMA trees based on $16 \mathrm{~S}$ rRNA and partial rpoB gene sequences are available as supplementary material with the online version of this paper. glucuronolyticum (Devriese et al., 2000) by phenotypic and genotypic identification. The aim of this polyphasic study was to describe the isolation and characterization of this novel organism.

A groin abscess specimen was collected at Olive ViewUCLA Medical Center in 2006, and studied in the Wadsworth Anaerobic Laboratory (WAL). One isolate derived from this specimen, WAL $19168^{\mathrm{T}}$, was analysed by phenotypic and genotypic characterization methods.

Optimal growth conditions were investigated by cultivating strain WAL $19168^{\mathrm{T}}$ aerobically and anaerobically on trypticase soy agar with 5\% sheep blood (TSA-II; Becton Dickinson Microbiology Systems) at 20, 37 and $42{ }^{\circ} \mathrm{C}$. Lipid requirement was determined by comparison between the culture in simple brain heart infusion (BHI) broth (MP Biomedicals) and in the same medium supplemented with $1 \%$ Tween 80 after 72 h at $37{ }^{\circ} \mathrm{C}$ (Riegel et al., 1994). Further confirmation of lipid stimulation of growth was observed by the 'response to serum' test (Coyle \& Lipsky, 1990).

Strain WAL $19168^{\mathrm{T}}$ and reference strains were characterized by routine tests (Devriese et al., 2000; Wattiau et al., 
2000) including Gram staining, API Coryne and API ZYM strips (bioMérieux) and susceptibility to the vibriostatic

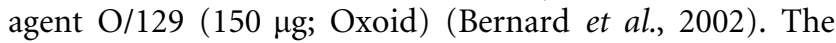
Christie-Atkins-Munch-Petersen (CAMP) reaction and fermentative test from fructose were confirmed by conventional methods (Riegel et al., 1994, 1995). The reference strains included in the above procedures were $C$. glucuronolyticum CCUG $35055^{\mathrm{T}}$, C. urealyticum CCUG $18158^{\mathrm{T}}$, C. accolens CCUG $28779^{\mathrm{T}}$ and C. jeikeium CCUG $27192^{\mathrm{T}}$, received from the Culture Collection of the University of Göteborg. Additionally for strain WAL $19168^{\mathrm{T}}$, susceptibility to antibiotics $(0.016-256 \mu \mathrm{g}$ ampicillin $\mathrm{ml}^{-1}, 0.002-32 \mu \mathrm{g}$ ceftriaxone $\mathrm{ml}^{-1}, 0.016-256 \mu \mathrm{g}$ clindamycin $\mathrm{ml}^{-1}$ and $0.016-256 \mu \mathrm{g}$ erythromycin $\mathrm{ml}^{-1}$ ) was studied by the Etest system (AB Biodisk) with MIC value confirmation according to the Clinical and Laboratory Standards Institute (CLSI) guidelines. $\beta$ Lactamase activity was assayed by the nitrocefin disc test (Biotech Diagnostics). All strains were cultured under the same conditions and tests were performed in duplicate with $24-48 \mathrm{~h}$ pure cultures according to the manufacturers' instructions, unless otherwise noted.

For cellular fatty acid (CFA) and metabolic end product (ME) (short-chain volatile and non-volatile fatty acids) analyses, the strains were grown in BHI broth supplemented with $1 \%$ glucose and $5 \%$ rabbit serum (MP Biomedicals). CFAs of the strains were detected with a Hewlett Packard 5890 series II gas chromatograph, while MEs were tested by GLC equipped with a flame-ionization detector (Finegold et al., 2004). Short-chain mycolic acids were investigated by a reversed-phase HPLC method (De Briel et al., 1992). Microbial Identification System software (MIDI, Inc.) was applied to generate and analyse the profiles of MEs and CFAs, as described previously (Song et al., 2006).

Genomic DNA of strain WAL $19168^{\mathrm{T}}$ was extracted and purified using a QIAamp DNA Mini kit (Qiagen). PCRs were used for the amplification of the 16S rRNA gene (Song et al., 2003) and the partial $r p o B$ gene (with primers C2625F and C3130R) (Khamis et al., 2004). The products were sequenced directly on a 3130 Genetic Analyzer (Applied Biosystems). The sequences obtained were compared with sequences in the GenBank database by using BLAST software (Brosius et al., 1978); similarity searches were performed with CLUSTAL $\mathrm{W}$ and distance matrices were created with respect to $1409 \mathrm{bp}$ of the $16 \mathrm{~S}$ rRNA gene sequence and 508 bp of the partial rpoB gene sequence. The neighbour-joining (Saitou \& Nei, 1987) and UPGMA (Sneath \& Sokal, 1973) methods were used to construct phylogenetic trees. The DNA G $+\mathrm{C}$ content of the novel organism was determined by HPLC (Mesbah et al., 1989). A DNA-DNA reassociation test between strain WAL $19168^{\mathrm{T}}$ and C. glucuronolyticum CCUG $35055^{\mathrm{T}}$ was done by using photobiotin-labelled probes in microplate wells (Ezaki et al., 1989).

Strain WAL $19168^{\mathrm{T}}$ was recovered from the groin abscess with a count of $10^{8}$ c.f.u. $\mathrm{ml}^{-1}$, accompanied by strains of Actinomyces radingae $\left(10^{8}\right.$ c.f.u. $\left.\mathrm{ml}^{-1}\right)$, Propionibacterium avidum $\left(10^{8}\right.$ c.f.u. $\left.\mathrm{ml}^{-1}\right)$ and Propionibacterium acnes $\left(10^{7}\right.$ c.f.u. $\mathrm{ml}^{-1}$ ). As with C. glucuronolyticum, strain WAL $19168^{\mathrm{T}}$ was able to grow on TSA-II plates at 37 and $42{ }^{\circ} \mathrm{C}$ aerobically as well as anaerobically after 2 days of incubation, but not at $20{ }^{\circ} \mathrm{C}$. In addition, growth was visible in $\mathrm{BHI}$ broth supplemented with $1 \%$ Tween 80 but not in non-supplemented infusion, better under aerobic conditions than in an anaerobic jar, and more abundant at 37 than at $42{ }^{\circ} \mathrm{C}$. The most profuse growth was exhibited in serum-supplemented liquid medium. In contrast to the opaque and whitish-pale colonies (1-1.5 $\mathrm{mm}$ in diameter) of C. glucuronolyticum, the colonies of strain WAL $19168^{\mathrm{T}}$ were small (0.3-0.5 $\mathrm{mm}$ in diameter), circular, entire, convex and translucent (Fig. 1). Blood plates on which C. glucuronolyticum CCUG $35055^{\mathrm{T}}$ was grown turned tan after approximately $24 \mathrm{~h}$ of incubation, while plates on which strain WAL $19168^{\mathrm{T}}$ was inoculated did not change colour until $72 \mathrm{~h}$ later. Microscopy revealed that the cells of strain WAL $19168^{\mathrm{T}}$ were Gram-positive, non-motile and rod-shaped, with occasional swellings.

According to tests on the API Coryne strip (code 2200725), the novel isolate was pyrazinamidase- and catalase-positive, weakly positive for pyrrolidonyl arylamidase and negative for gelatin hydrolysis, urease and reduction of nitrate. It could use D-ribose slightly and was able to ferment Dxylose, D-glucose, maltose and sucrose, but was unable to utilize D-mannitol, lactose (bovine origin) and glycogen. The API ZYM strip revealed that strain WAL $19168^{\mathrm{T}}$ could produce esterase $(\mathrm{C} 4)$, esterase lipase $(\mathrm{C} 8)$, leucine arylamidase and a little naphthol-AS-BI-phosphohydrolase. The reactions for acid phosphatase, lipase (C14), valine arylamidase, cystine arylamidase, trypsin, $\alpha$-chymotrypsin, $\alpha$-galactosidase, $\alpha$-fucosidase and $\alpha$-mannosidase were negative. API Coryne and API ZYM strips both gave positive reactions for $\beta$-glucuronidase and negative tests for $\alpha$-glucosidase, $\beta$-galactosidase, $N$-acetyl- $\beta$-glucosamini-
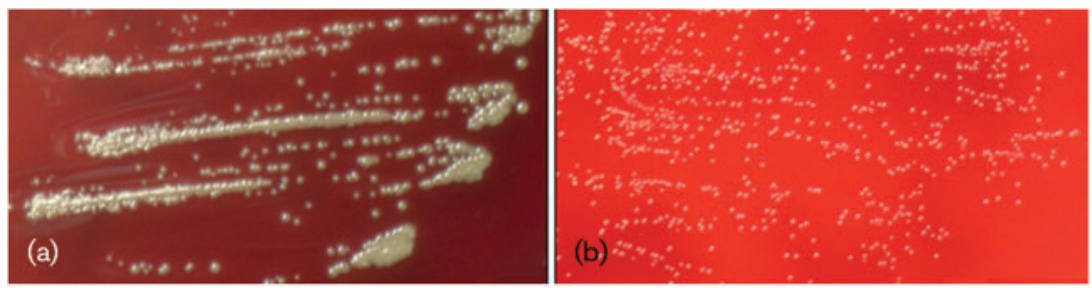

Fig. 1. Colonial appearance of C. glucuronolyticum CCUG $35055^{\top}$ (a) and strain WAL $19168^{\top}$ (b) on TSA-II plates after 2 days of incubation. Note the differences in the size of colonies and the colour of the plates. 
dase, alkaline phosphatase and $\beta$-glucosidase. Strain WAL $19168^{\mathrm{T}}$ showed negative results in the CAMP and fructose fermentation reactions by traditional procedures. In comparison with the reference strains, WAL $19168^{\mathrm{T}}$ exhibited some distinct biochemical characteristics which are useful for clinical identification, as shown in Table 1. In addition, it could not produce $\beta$-lactamase and was susceptible to the lowest concentrations of antibiotics included. All the strains investigated in this study were sensitive to the $\mathrm{O} / 129$ agent.

The main CFA detected in strain WAL $19168^{\mathrm{T}}$ was $\mathrm{C}_{18: 1} \omega 9 c$, comprising $28 \%$ of the total fatty acids. No tuberculostearic acid (TBSA; 10-methyl $\mathrm{C}_{18: 0}$ ) was found; other CFAs detected at $10 \%$ or more of the total fatty acids were $\mathrm{C}_{16: 0}$ and summed feature $8\left(\mathrm{C}_{17: 1} \omega 8 c\right.$ and/or $\left.\mathrm{C}_{17: 2}\right)$. Short-chain mycolic acids $\left(\mathrm{C}_{22}-\mathrm{C}_{36}\right)$ were present. Strain WAL $19168^{\mathrm{T}}$ could utilize glucose and produced a small amount of propionic acid; the major MEs were acetic acid (volatile fatty acid; $494 \mathrm{mg} \mathrm{ml}^{-1}$ ) and pyruvic acid (nonvolatile fatty acid; $817 \mu \mathrm{g} \mathrm{ml}^{-1}$ ).

Table 1. Biochemical characteristics of strain WAL $19168^{\top}$ and the type strains of related species

Strains: 1, C. pyruviciproducens sp. nov. WAL $19168^{\mathrm{T}} ; 2$, C. glucuronolyticum CCUG $35055^{\mathrm{T}}$; 3, C. urealyticum CCUG $18158^{\mathrm{T}}$; 4 , C. accolens CCUG $28779^{\mathrm{T}}$; 5, C. jeikeium CCUG $27192^{\mathrm{T}}$. + , Positive; - , negative; w, weakly positive reaction. Data were obtained in this study.

\begin{tabular}{|lccccc|}
\hline Characteristic & $\mathbf{1}$ & $\mathbf{2}$ & $\mathbf{3}$ & $\mathbf{4}$ & $\mathbf{5}$ \\
\hline API Coryne code & 2200725 & 7241125 & 2101004 & 7100324 & 2100304 \\
CAMP reaction & - & + & - & - & - \\
Reduction of & - & + & - & + & - \\
nitrates & & & & & \\
Production of: & & & & & \\
$\beta$-Glucuronidase & + & + & - & - & - \\
Alkaline & - & - & W & + & + \\
phosphatase & & & & & \\
$\beta$-Glucosidase & - & + & - & - & - \\
Urease & - & + & + & - & - \\
Cystine & - & + & - & - & - \\
arylamidase & & & & & \\
Acid & - & + & - & - & + \\
phosphatase & & & & & \\
Leucine & + & + & - & + & - \\
arylamidase & & & & & \\
Lipase (C14) & - & - & W & - & + \\
Esterase (C4) & W & w & + & + & + \\
Fermentation of: & & & & & \\
Fructose & - & + & - & + & - \\
D-Ribose & w & - & - & + & + \\
Maltose & + & + & - & + & - \\
D-Glucose & + & + & - & + & + \\
Sucrose & + & + & - & - & - \\
D-Xylose & + & - & - & - & - \\
& & & & & \\
\hline
\end{tabular}

Comparisons based on the GenBank database showed that the closest match to strain WAL $19168^{\mathrm{T}}$ was C. glucuronolyticum CCUG $35055^{\mathrm{T}}$, with $96.8 \%$ sequence similarity for the $16 \mathrm{~S}$ rRNA gene sequence and $90.6 \%$ sequence similarity for the partial $r p o B$ gene sequence. The DNA $\mathrm{G}+\mathrm{C}$ content of strain WAL $19168^{\mathrm{T}}$ is $62 \mathrm{~mol} \%$. This is within the range described for the genus Corynebacterium (51-70 mol\%; Cerdeño-Tárraga et al., 2003). A DNADNA reassociation study between strain WAL $19168^{\mathrm{T}}$ and C. glucuronolyticum CCUG $35055^{\mathrm{T}}$ showed a reassociation value of $13.3 \%$ ( $13.7 \%$ on repeat analysis), confirming that they are members of distinct species. Phylogenetic trees derived from alignments of the $16 \mathrm{~S}$ rRNA and $r p o B$ gene sequences are shown in Fig. 2 and Supplementary Fig. S1 (available in IJSEM Online).

The novel coryneform currently described is evidently lipophilic, based on our research on its growth conditions. We therefore chose the type strains of several medically significant lipophilic Corynebacterium species, i.e. C. jeikeium, C. urealyticum and C. accolens, as reference strains in addition to genetically related species. They are the members of coryneform CDC groups JK, D and G, respectively (Coyle \& Lipsky, 1990; Pitcher et al., 1992; Neubauer et al., 1991). In our research, strain WAL $19168^{\mathrm{T}}$ possessed a strongly positive catalase reaction, in common with other members of the genus Corynebacterium. However, it is known that the identification of members of the genus Corynebacterium is difficult in clinical and reference laboratories (Clarridge, 1986; Sabbe et al., 1999). The API Coryne strip of strain WAL $19168^{\mathrm{T}}$ in our study gave the result 'Corynebacterium glucuronolyticum with 99.9\% ID'. Therefore, more supplementary tests should be performed to help classification, such as the CAMP test, fermentative activity from fructose and production of cystine arylamidase and acid phosphatase. In addition, the novel organism can be differentiated from important lipophilic strains by $\beta$-glucuronidase production and D-xylose fermentation tests. Regarding the CFAs of the novel strain, we did not find significant differences from the profiles of other Corynebacterium species (Van den Velde et al., 2006). It should be noted that this strain was able to metabolize glucose and produce pyruvic acid at high concentrations, which can be useful in identifying the novel organism, although they are not unique characteristics within the genus Corynebacterium. Pyruvic acid is the major metabolic intermediate during the metabolic cycle of corynebacteria and can be produced by several species (Rollin et al., 1995), but most of these are mutant strains developed for industrial purposes. So far, no Corynebacterium species recovered from human sources has been reported to have this ability.

Previously, it has been recognized that a $16 \mathrm{~S}$ rRNA gene sequence divergence of $3 \%$ or more was significant, and DNA-DNA reassociation was generally regarded as the primary molecular tool to delineate species when a novel species was being studied (Stackebrandt \& Goebel, 1994). However, a recent study has revealed that sequence 
(a)
C. cystitidis NCTC $11863^{\top}$ (X84252) C. glutamicum NCIMB $10025^{\top}$ (Z46753) C. aurimucosum CCUG $47449^{\top}$ (AF220220) C. flavescens CIP 69.5 (X82060)

C. spheniscorum CCUG $45512^{\top}$ (AJ429234)

C. Inoophilfavum CCUG $37336^{\top}$ (Y09045)

C. camporealensis CECT $4897^{\top}$ (YO9569)

C. sundsvallense CCUG $36622^{\top}$ (Y09655)

6. C. tuscaniae ATCC BAA-1141 ${ }^{\top}$ (AY677186)

40 C. ureicelerivorans IMMIB RIV-2301' (AM397636)

C. accolens CIP 104783' (AJ439346)

95 C. mastitidis CECT $4843^{\top}$ (Y09806)

C. segmentosum NCTC $93^{\top}$ (X84437)

C. pilosum ATCC $29592^{\top}$ (X81908)

C. macginleyi CIP $104099^{\top}$ (AJ439345)

${ }_{96}$ C. mycetoides NCTC $9864^{\top}(X 84241)$

${ }_{43}{ }_{89}$ C. coyleae DSM $44184^{\top}$ (X96497)

C. renale CIP $103421^{\top}$ (X81909) 44 C. diphtheriae NCTC $11397^{\mathrm{T}}(\mathrm{X84248)}$

52 C. felinum CCUG $39943^{\top}$ (AJ401282)

${ }_{90}$ C. vitarumen NCTC $20294^{\top}\left(X_{84680}\right)$

$\stackrel{0.2}{\longmapsto}$

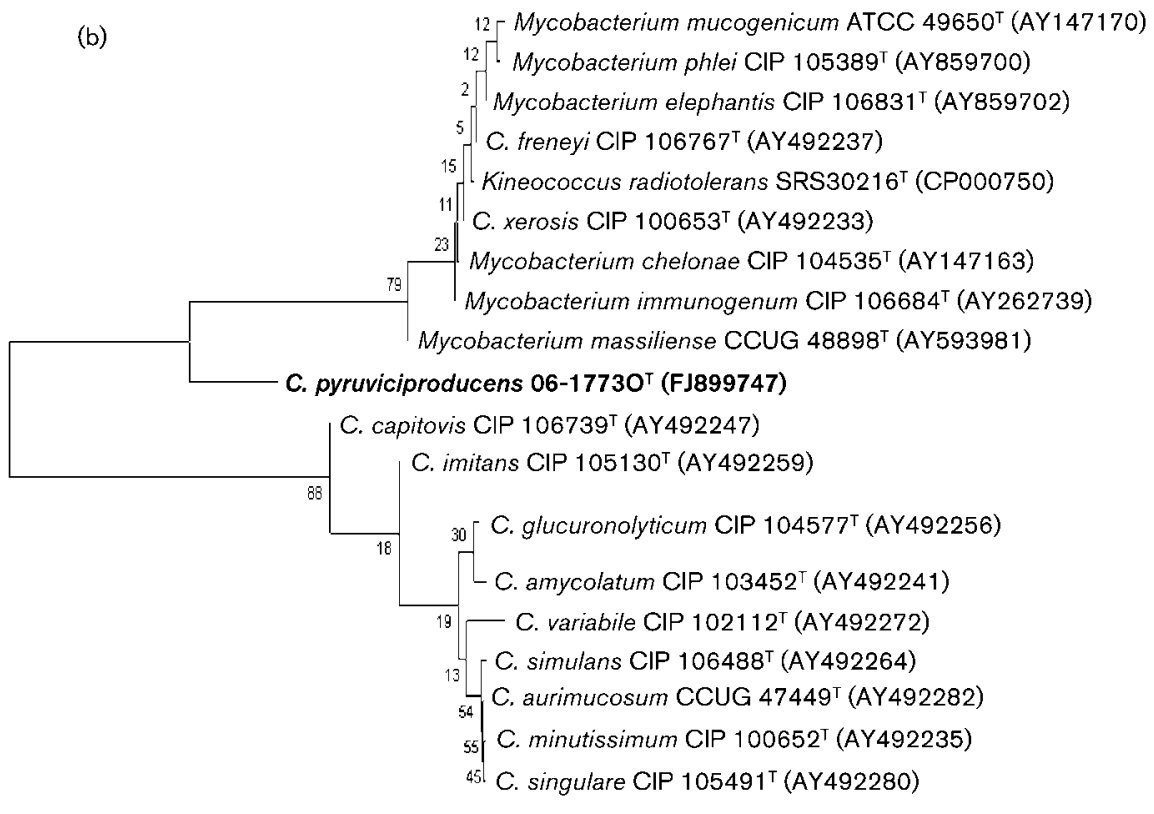

$\stackrel{1}{\longmapsto}$

Fig. 2. Neighbour-joining phylogenetic trees showing the position of strain WAL $19168^{\top}\left(=06-17730^{\top}\right)$, based on comparisons of $16 \mathrm{~S}$ rRNA gene sequences of 1409 bp (a) and partial rpoB gene sequences of $508 \mathrm{bp}$ (b). Bootstrap percentages (based on 1000 replications) are shown at branching points. GenBank accession numbers for each sequence are given in parentheses. Bars, 0.2 (a) and 1 (b) substitutions per site. 
similarity of the single-copy $r p o B$ gene can be an efficient supplement to these traditional taxonomic methods, since cases of distinct species exhibiting 16S rRNA gene sequence similarity $>99 \%$ are often found (Adékambi et al., 2008). Furthermore, an $r p o B$ gene sequence similarity of $>97.7 \%$ has already been confirmed to be useful in delineating species. In our study, $16 \mathrm{~S}$ rRNA gene sequence comparison and a similarity value of $90.6 \%$ for the partial $r p o B$ gene sequence indicated that the unknown bacterium isolated from a clinical wound specimen may well represent a new genospecies of Corynebacterium. All of the phylogenetic analyses demonstrate that the novel strain appears to represent a new subline of the genus Corynebacterium, for which the name Corynebacterium pyruviciproducens sp. nov. is proposed.

\section{Description of Corynebacterium pyruviciproducens sp. nov.}

Corynebacterium pyruviciproducens (py.ru.vi'ci.pro.du'cens. N.L. n. acidum pyruvicum pyruvic acid; L. part. adj. producens producing; N.L. part. adj. pyruviciproducens pyruvic acid-producing).

Gram-positive, non-spore-forming rods; non-motile. Lipophilic. Can grow aerobically or facultatively anaerobically at 37 and $42{ }^{\circ} \mathrm{C}$. Optimum growth at $37{ }^{\circ} \mathrm{C}$ under aerobic conditions. Colonies are small $(0.3-0.5 \mathrm{~mm}$ in diameter), circular, entire, convex and translucent after 2 days of incubation on blood agar. Strongly catalasepositive, but urease-negative. Cannot reduce nitrates and CAMP test is negative. Acid is produced from D-ribose, Dxylose, D-glucose, maltose and sucrose, but not from fructose, D-mannitol, lactose (bovine origin) or glycogen. Cells produce esterase (C4), esterase lipase (C8), leucine arylamidase, pyrazinamidase, a small amount of naphtholAS-BI-phosphohydrolase and pyrrolidonyl arylamidase, but no acid phosphatase, $\beta$-galactosidase, $\alpha$-glucosidase, $N$-acetyl- $\beta$-glucosaminidase, lipase (C14), valine arylamidase, cystine arylamidase, $\alpha$-chymotrypsin, $\alpha$-galactosidase, $\alpha$-fucosidase, alkaline phosphatase, $\alpha$-mannosidase or $\beta$ glucosidase. Trypsin and gelatin are not hydrolysed. $\beta$ Lactamase-negative. Susceptible to the vibriostatic agent $\mathrm{O} / 129$ and highly sensitive to ampicillin, ceftriaxone, clindamycin and erythromycin. The major cellular fatty acids are $\mathrm{C}_{18: 1} \omega 9 c, \mathrm{C}_{16: 0}$ and summed feature $8\left(\mathrm{C}_{17: 1} \omega 8 c\right.$ and/or $\left.\mathrm{C}_{17: 2}\right)$; no TBSA is produced. Short-chain mycolic acids $\left(\mathrm{C}_{22}-\mathrm{C}_{36}\right)$ are present. Major MEs from glucose are acetic acid and pyruvic acid.

The type strain is $06-1773 \mathrm{O}^{\mathrm{T}}\left(=\mathrm{WAL} 19168^{\mathrm{T}}=\mathrm{CCUG}\right.$ $57046^{\mathrm{T}}=$ ATCC BAA- $1742^{\mathrm{T}}$ ), isolated from a groin abscess specimen taken at Olive View-UCLA Medical Center in 2006. The DNA G $+\mathrm{C}$ content of the type strain is $62 \mathrm{~mol} \%$.

\section{Acknowledgements}

This work has been supported in part by DOD grant \# W81XWH0510134 and VA Merit Review funds.

\section{References}

Adékambi, T., Shinnich, T. M., Raoult, D. \& Drancourt, M. (2008). Complete $r p o B$ gene sequencing as a suitable supplement to DNADNA hybridization for bacterial species and genus delineation. Int $J$ Syst Evol Microbiol 58, 1807-1814.

Bernard, K. A., Munro, C., Wiebe, D. \& Ongsansoy, E. (2002). Characteristics of rare or recently described Corynebacterium species recovered from human clinical material in Canada. J Clin Microbiol 40, 4375-4381.

Brosius, J., Palmer, M. L., Kennedy, P. J. \& Noller, H. F. (1978). Complete nucleotide sequence of a $16 \mathrm{~S}$ ribosomal RNA gene from Escherichia coli. Proc Natl Acad Sci U S A 75, 4801-4805.

Cerdeño-Tárraga, A. M., Efstratiou, A., Dover, L. G., Holden, M. T. G., Pallen, M., Bentley, S. D., Besra, G. S., Churcher, C., James, K. D. \& other authors (2003). The complete genome sequence and analysis of Corynebacterium diphtheriae NCTC 13129. Nucleic Acids Res 31, 6516-6523.

Clarridge, J. E. (1986). When, why, and how far should coryneforms be identified? Clin Microbiol Newsl 8, 5-7.

Coyle, M. B. \& Lipsky, B. A. (1990). Coryneform bacteria in infectious diseases: clinical and laboratory aspects. Clin Microbiol Rev 3, 227246.

De Briel, D., Couderc, F., Riegel, P., Jehl, F. \& Minck, R. (1992). Highperformance liquid chromatography of corynomycolic acids as a tool in identification of Corynebacterium species and related organisms. J Clin Microbiol 30, 1407-1417.

Devriese, L. A., Riegel, P., Hommez, J., Vaneechoutte, M., Baere, T. D. \& Haesebrouck, F. (2000). Identification of Corynebacterium glucuronolyticum strains from the urogenital tract of humans and pigs. J Clin Microbiol 38, 4657-4659.

Dowd, S. E., Wolcott, R. D., Sun, Y., McKeehan, T., Smith, E. \& Rhoads, D. (2008). Polymicrobial nature of chronic diabetic foot ulcer biofilm infections determined using bacterial tag encoded FLX amplicon pyrosequencing (bTEFAP). PLoS One 3, e3326.

Ezaki, T., Hashimoto, Y. \& Yabuuchi, E. (1989). Fluorometric deoxyribonucleic acid-deoxyribonucleic acid hybridization in microdilution wells as an alternative to membrane filter hybridization in which radioisotopes are used to determine genetic relatedness among bacterial strains. Int J Syst Bacteriol 39, 224-229.

Feurer, C., Clermont, D., Bimet, F., Candréa, A., Jackson, M., Glaser, P., Bizet, C. \& Dauga, C. (2004). Taxonomic characterization of nine strains isolated from clinical and environmental specimens, and proposal of Corynebacterium tuberculostearicum sp. nov. Int J Syst Evol Microbiol 54, 1055-1061.

Finegold, S. M., Vaisanen, M., Rautio, M., Eerola, E., Summanen, P., Molitoris, D., Song, Y. L., Liu, Ch. X. \& Somer, H. J. (2004). Porphyromonas uenonis sp. nov., a pathogen for humans distinct from P. asaccharolytica and P. endodontalis. J Clin Microbiol 42, 52985301.

Finegold, S. M., Talan, D., Hiyama, S., Rowlinson, M.-C., Summanen, P., Molitoris, D., Liu, C.-X., Ulger, N., Wooton, J. \& other authors (2008). Analysis of 400 surgical and traumatic wound infections and closed abscesses by molecular techniques for development of a real-time PCR procedure. In Abstracts of the 108th General Meeting of the American Society for Microbiology, Boston, MA, 1-5 June 2008, abstract C-110. Washington, DC: American Society for Microbiology.

Hommez, J., Devriese, L. A., Vaneechoutte, M., Riegel, P., Butaye, P. \& Haesebrouck, F. (1999). Identification of nonlipophilic corynebacteria isolated from dairy cows with mastitis. J Clin Microbiol 37, 954-957. 
Khamis, A., Raoult, D. \& La Scola, B. (2004). $r p o B$ gene sequencing for identification of Corynebacterium species. J Clin Microbiol 42, 3925-3931.

Mesbah, M., Premachandran, U. \& Whitman, W. B. (1989). Precise measurement of the $\mathrm{G}+\mathrm{C}$ content of deoxyribonucleic acid by highperformance liquid chromatography. Int J Syst Bacteriol 39, 159-167.

Neubauer, M., Sourek, J., Ryc, M., Bohacek, J., Mara, M. \& Mnukova, J. (1991). Corynebacterium accolens sp. nov., a gram-positive rod exhibiting satellitism, from clinical material. Syst Appl Microbiol 14, 46-51.

Paviour, S., Musaad, S., Roberts, S., Taylor, G., Taylor, S., Shore, K., Lang, S. \& Holland, S. (2002). Corynebacterium species isolated from patients with mastitis. Clin Infect Dis 35, 1434-1440.

Pitcher, D., Soto, A., Soriano, F. \& Valero-Guilién, P. (1992). Classification of coryneform bacteria associated with human urinary tract infection (group D2) as Corynebacterium urealyticum sp. nov. Int J Syst Bacteriol 42, 178-181.

Riegel, P., Briel, D., Prévost, G., Jehl, F. \& Monteil, H. (1994). Genomic diversity among Corynebacterium jeikeium strains and comparison with biochemical characteristics and antimicrobial susceptibilities. J Clin Microbiol 32, 1860-1865.

Riegel, P., Ruimy, R., Briel, D., Prévost, G., Jehl, F., Bimet, F., Christen, R. \& Monteil, H. (1995). Corynebacterium seminale sp. nov., a new species associated with genital infections in male patients. J Clin Microbiol 33, 2244-2249.

Rollin, C., Morgant, V., Guyonvarch, A. \& Guerquin-Kern, J. L. (1995).

${ }^{13} \mathrm{C}-\mathrm{NMR}$ studies of Corynebacterium melassecola metabolic pathways.

Eur J Biochem 227, 488-493.
Sabbe, L. J., Van De Merwe, D., Schouls, L., Bergmans, A., Vaneechoutte, M. \& Vandamme, P. (1999). Clinical spectrum of infections due to the newly described Actinomyces species A. turicensis, A. radingae, and A. europaeus. J Clin Microbiol 37, 8-13.

Saitou, N. \& Nei, M. (1987). The neighbor-joining method: a new method for reconstructing phylogenetic trees. Mol Biol Evol 4, 406425.

Sneath, P. H. A. \& Sokal, R. R. (1973). Numerical Taxonomy. The Principles and Practice of Numerical Classification. San Francisco: W. H. Freeman.

Song, Y. L., Liu, Ch. X., McTeague, M. \& Finegold, S. M. (2003). $16 \mathrm{~S}$ ribosomal DNA sequence-based analysis of clinically significant gram-positive anaerobic cocci. J Clin Microbiol 41, 13631369.

Song, Y., Könönen, E., Rautio, M., Liu, C., Bryk, A., Eerola, E. \& Finegold, S. M. (2006). Alistipes onderdonkii sp. nov. and Alistipes shahii sp. nov., of human origin. Int J Syst Evol Microbiol 56, 19851990.

Stackebrandt, E. \& Goebel, B. M. (1994). Taxonomic note: a place for DNA-DNA reassociation and 16S rRNA sequence analysis in the present species definition in bacteriology. Int J Syst Bacteriol 44, 846849.

Van den Velde, S., Lagrou, K., Desmet, K., Wauters, G. \& Verhaegen, J. (2006). Species identification of corynebacteria by cellular fatty acid analysis. Diagn Microbiol Infect Dis 54, 99-104.

Wattiau, P., Janssens, M. \& Wauters, G. (2000). Corynebacterium simulans sp. nov., a non-lipophilic, fermentative Corynebacterium. Int J Syst Evol Microbiol 50, 347-353. 